\title{
IMPROVING THE LEGISLATIVE PROCESS: FEDERAL REGULATION OF LOBBYING
}

IN a world in which the center of political gravity is shifting from legislature to executive the Legislative Reorganization Act of $1946^{1}$ represents an attempt by Congress to reassess and strengthen its position as an integral part of representative government. ${ }^{2}$ Congress has recognized the need for reorganizing and streamlining the decision making process if it is to recapture its position as the dominant policy determining branch of government. Reformation of the standing committees, ${ }^{3}$ increased use of governmental experts, ${ }^{4}$ higher salaries for members, ${ }^{5}$ prohibition of private legislation, ${ }^{0}$

1. Pub. L. 601, 79th Cong., 2nd Sess. (Aug. 2, 1946) (hereafter cited by section only). The Act is the product of the Joint Committee on the Organization of Congress, of which Senator LaFollette (Wis.) was chairman and Representative Monroney (Okla.) vicechairman.

2. "Our committee was created in response to a widespread congressional and public belief that a grave constitutional crisis exists in which the fate of representative governntent itself is at stake. Public affairs are now handled by a host of administrative agencies headed by nonelected officials with only casual oversight by Congress. The course of events has created a breach between government and the people. Behind our inherited constitutional pattern a new political order has arisen which constitutes a basic change in the federal design. Meanwhile, government by administration is the object of group pressures which weaken its protection of the public interest. Under these conditions . . . the time is ripe for Congress to reconsider its role in the American scheme of government and to modernize its organization and procedures." SEN. REP. No. 1011, 79th Cong., 2nd Sess. (1946) 1. The Joint Committee made recommendations for congressional reorganization in this report. A subsequent report was submitted discussing the Act as drafted by the committee with the assistance of the Office of Legislative Counsel. See SEN. REP. No. 1400, 79th Cong., 2nd Sess. (1946). Both reports will hereafter be cited by number only.

3. Sections 102,121. The 33 standing committees of the Senate and the 48 standing committees of the House are reduced to 15 and 19 respectively, thus eliminating many repetitive and overlapping functions previously performed. Regularization of committee procedure in respect to hearings, meetings, and record-keeping as well as definition of committec powers are all provisions designed to make more efficient utilization of both time and personnel. An unavoidable weakness of these sections is that they have only the force of Rules of the respective houses, and either may revoke provisions applicable to it. Opposition of legislators with vested interests in former committees may result in the mushrooming of new standing committees over a period of time. Although there is no indication that the number of standing committees will be increased by the 80th Congress, a growth in the number of special committees might also vitiate these provisions.

4. Sections 202, 203, 204. Appropriations to the Legislative Reference Bureall and the Office of Legislative Counsel are to be increased from $\$ 198,000$ to $\$ 750,000$ and $\$ 90,000$ to $\$ 250,000$ respectively in the hope that these services will be improved both in the quality of their work and in the number of legislators served. Other provisions provide for the employment of four experts to advise each standing committee and improved clerical aid. The original bill went even further in providing for an administrative assistant for each congressman and the establishment of an Office of Congressional Personnel designed to end the socalled patronage system. S. 2177, 79th Cong. 2nd Sess. (1946) $\S \S 201,204$. Opposition to the loss of such a political bonanza prevented their becoming a part of the Act. See 92 Cong. Rec., June 8, 1946, at 6654-6. 
regulation of lobbying activities ${ }^{7}$ are all methods of improving the intelligence function of government so as to increase the probability of rational legislative decision.

The provisions of the Act which regulate lobbying are, therefore, to be regarded as one element in a larger scheme to improve present political processes. Democratic political theory assumes that rational decision can best be reached after hearing and evaluating the interests of the component members of society. These interests are in theory expressed by individuals through the medium of their elected representatives in the legislature. Election of these representatives on a geographical basis overlooks the fact that individuals identify their interests not only with a state or political subdivision, but more importantly with a business, economic, social, or fraternal group. Technological advances in communication and transportation have facilitated group interests which are no longer confined within political boundaries. The failure of the Constitution to provide for group representation, the decline of the political party as a prompter of opinion and policy, the intrusion of government into virtually all fields of economic activity, and the increasing complexity of modern legislative problems have led to the development of a powerful extra-legal machinery for achieving group aims. Today legislation is the result of a compromise between these conflicting group interests, but survival of geographical representation largely obscures the functional basis for legislative action.

Two groups have advanced remedies designed to reconcile the existing fact situation with political theory. The first seeks a means by which group interests can be fitted into the formal pattern of government, a system of functional representation as a substitute for, or supplement to, existing political institutions. ${ }^{8}$ On the other hand, a second group regards the problem

5. Section 601 . The original bill proposed a flat $\$ 15,000$ salary but this was amended in the House to include only a $\$ 2,500$ increase and continuance of the previous $\$ 2,500$ taxexempt expense allowance.

6. Section 131. The provisions of Title IV (Federal Tort Claims Act) which transfer adjudication of tort claims from Congress to the federal courts or, in minor instances, to the administrative agency involved and Title V (General Bridge Act), which eliminate the necessity of Congressional approval for the construction of bridges over navigable streams, are complementary to the ban on private legislation.

7. Section 301 et seq. Section 301 provides that Title III of the Act may be cited as the Federal Regulation of Lobbying Act. See Comment (1947) 47 CoL. L. Rev. 98.

8. Proposals for functional representation have never been as well received in the United States as in Europe. Political scientists have suggested constitutional revisions designed to eliminate the geographical system. See, for example, MincDosuld, A NEW Cos:STITUIION FOR A NEW AMERICA (1921). But practical efforts have been limited to proposals for advisory councils to represent economic interests as a supplement to geographical representation.In 1931 Senator LaFollette introduced a bill embodying this concept in Congress. See S. 6215, 71st Cong., 3rd Sess. (1931). Such a body to advise the executive mas suggested by President Hoover's Research Committee on Social Trends, Recent Socrar TrEeids Ii the UNited States (1933). Pressure groups, notably the National Lumber Manufacturers Association and the United Steelworkers (CIO), have expressed approval of the idea. 
of representation as subordinate to a rationalization of the whole legislative process. Their emphasis is upon administrative efficiency, extension of federal research and information services, increased governmental planning, and bringing "lobbying" activities into the open. It is this view which Congress has espoused in the Reorganization Act. ${ }^{9}$

\section{The PRoBLEM}

If lobbying is defined in its broadest terms as any attempt by individuals or groups to influence governmental decision, it is apparent that in some form it inheres in all government. ${ }^{10}$ American history is full of examples of legislation passed at the instance of, and for the benefit of, special interests. ${ }^{11}$ But lobbying today is both qualitatively and quantitatively a different problem from lobbying in the past. Whereas the old-style lobby, confined almost entirely to representatives of business interests, operated secretly and depended for its success upon personal solicitation of legislators, often accompanied by corruption, such methods are largely obsolete today. ${ }^{12}$ Modern lobbyists, or

Statement of Robert K. Lamb, Hearings before the Joint Committee on lite Organization of Congress pursuant to H. Con. Res. 18, 79th Cong., 1st Sess. (1945) 1013.

Parliaments of industry or advisory councils have been widely adopted in Europe. Results in these countries have not, however, indicated that a formal joining of politics and economics is an effective solution to the problem of pressure groups. Herring, Legalized Lobbying in Europe (1930) 31 CuRRENT HISTORY 947. For more general discussions of groupism see Cole, Guild Soctalism Restated (1920); Dugutt, Law in the Modern State (1919); Laski, Grammar of Politics (1925); Wallas, the Great Society (1914).

9. A full discussion of the congressional reorganization is found in GALloway, CoNGRESS AT THE CROSSROADS (1946). Dr. Galloway was advisor to the joint committee which drafted the bill. See also, Report of the Committee on Congress of the American Political Science Association, The Reorganization of Congress (1945); Simmons, Reorganization of the Federal Government (1945) 31 A. B. A. J. 63.

10. In general see Blaisdell, TNEC REP., Economic Power aNd Political Pressure, Monograph No. 26 (1941); Chase, Democracy Under Pressure (1945); Crawford, The Pressure Boys (1939); Herring, Group Representation Before Congress (1929); Lobby, 9 ENCyc. Soc. Scrences 565 (1933); Boeckel, Regulation of Congressional Lobbies (1928) 1 Ed. REs. REp. 207; Brewer, Congressional Lobbying (1946) 1 id. 317; Logan, Lobbying (1929) 144 The Annals (July Supp.); Pressure Grotus and Propaganda (1935) 179 id., passinr. More specialized studies which throw light on the pressure group problem are Schattschnetder, Politics, Pressures and the Tariff (1935) and Zellek, Pressure POLITICS IN NEW'YORK (1937).

11. See Merriam, American Party Systedr (1923) 113 el seq.; Odegard, Lobbies and American Legislation (1930) 31 CURRENT History 690,692. A recent study of 90 major laws disclosed that pressure groups were important in securing passage in every case, and that seven of these laws were in effect enacted by pressure groups, both the President and Congress subordinating their views to those of powerful lobbies. Chamberlain, The President, Congress, and Legislation (1946) 61 PoL. Scr. Q. 42, 49.

12. Discussions of the old-style lobby are found in Herring, op. cit. supra note 10, at 30-40; Boeckel, supra note 10 at 211-14; 2 Poore, Perrex'ś Reariniscences (1886) 515 et seq. Occasionally the corruption resulted in a national scandal such as that which accompanied the operations of Cornelius Wendell, creator of the infamous "whiskey ring" during the administration of President Grant. The investigation of the Credit Mobilier in 1872 
legislative agents, act on behalf of almost every conceivable business, economic, and social group, ${ }^{13}$ generally operate openly and frankly, ${ }^{14}$ and rely upon public opinion, real or stimulated through judicious use of publicity and propaganda, to compel legislative action.

Fundamental reasons for the transition from old to new lobby are to be found in the same considerations which have given rise to demands for functional representation. ${ }^{15}$ As the technological barriers to group organization on a national scale have been removed, the common interests of workers, farmers, professional men and social reformers have led each to strive to participate in governmental decisions. Increased public scrutiny of the legislative process, a consequence of the growth of radio and press services, has made legislators more conscious of the force of public opinion. Pressure groups with large memberships are an effective threat to an elective office holder through the votes they control and the large segment of public opinion they represent; those with a smaller popular base can secure legislative consideration of their proposals only by stimulating or feigning public approbation.

Legislative investigations aimed at disclosing the extent of lobbying practices bear striking testimony to the effectiveness ${ }^{16}$ of utilization of mass

likewise revealed distribution of stock, free passes, telegraph and express franks to members of Congress. The old lobby center was Pendleton's Game Rooms, the "Hall of the Bleeding Heart," on Pennsylvania Avenue, where bribes were passed to impecunious legislators in the form of card winnings. Corrupt practices are still occasionally resorted to today. See the revelations of the activities of Robert Smith by the Blacl Investigating Committee, discussed in 27 Tnse (Mar. 30, 1936) 15-16, and the more recent disclosures of the Mead Committee Investigation of War Contracts, N. Y. Times, July 18, 1946, p. 1, col. 6. The greatest temptation to resort to bribery seems to be found in the amarding of contracts by governmental agencies.

13. Estimates as to the number of lobbyists in Washington vary widely. One writer puts the number at 6,000 . CRATFORD, op. cit. supra note 10, at 3 . A more consonative figure is 400 , a number of which are ineffective. See Herrisg, op. cit. stipra note 10, at 276-83; BLAISDELL, op. cit. supra note 10, at 197. The list compiled by Herring in 1929 mas used as the basis for TNEC compilation in 1940 and found substantially accurate. But various Washington correspondents estimate the number to have doubled during the war. Sa Brewer, supra note 10, at 322, n. 10; Mechling, Washinglon Lobbies Thrcalen Democracy (1946) 22 VA. Q. REv. 321.

14. Since the power of modern pressure groups depends on the number of vates they control and their influence on public opinion there is little to gain from concealing their identity. For this reason many lobbyists, who represent groups with a large popular bace, favor registration laws which will eliminate the "fake" lobbyist who represent non-evistent groups. Furthermore, official recognition of their activities may serve to enhance their prestige. See Logan, supra note 10, at 73.

15. Other reasons advanced are (1) Reform of the House Rules in 1911; (2) Adoption of the practice of open committee hearings; (3) Direct election of Senators persuant to the 17 th amendment; (4) The lobby investigations of 1913 . Herrisg, op. cil. stipra note 10 , at 41-6. Much of the old-time corruption may have been traceable to the system of closed committee hearings. See Winson, Congressional Governarent (1855) 189-90.

16. See Beale, Are Aarerican Teachers Free? (1936); Ruup, Education and Organized INTERests in AMerica (1936); Brindze, Not to be Broddcist (1937); Deni- 
channels of propaganda provided by the newspaper, the radio, the school, the theater, and the church. Pressure can be brought on legislators by publicity campaigns designed to prompt constituents, within or without the pressure group, to bring influence to bear by writing letters or sending telegrams; ${ }^{17}$ at election dates, candidates, regardless of party affiliation, ${ }^{18}$ considered favorably disposed toward group interests can be supported by the organization; or public opinion can be skillfully moulded to identify the public interest with legislation favored by the group.

To supplement these indirect methods of influencing legislation most pressure groups maintain a Washington expert, and a technical information service. The expert, or lobbyist, makes the group's views known to legislators either through direct contact, testimony before committees ${ }^{19}$ or the submission of written statements, often carefully documented by highly paid legal counsel. He undertakes to provide extensive factual surveys to support his position, analyze legislation, draft bills, or perform any other service the congressman may desire. In addition he keeps the organization posted on the status of bills in committee or on the floor which may affect the group.

Even if no practical or constitutional ${ }^{20}$ difficulties were encountered, few

son, Editorial Policies of Broadcasting Companies (1937) 1 Public Opinion Quarterly 64. A complete bibliography on propaganda techniques can be found in SMrTH, LAssweL and Casey, Propaganda, Communication, and Public Opinion (1946); Lasswell, Casey and Smiti, Propaganda and Promotional Activities (1935).

17. There is some disagreement as to the effectiveness of these practices. Where the inspiration is obviously from a pressure group, as in the case of form letters or telegrams, the legislator is not likely to be influenced. But the contrary is true where the communication appears to be the genuine expression of opinion by a constituent. Needless to say it is often hard to detect the existence of the pressure group in the background. As to the effectiveness of such pressure devices see Zeller, Modern Pressure Groups (1939) 29 Axr. LAB. LEG. REv. 152, 155; Odegard, supra note 11 at 694; But see Statement of Senator McClellan, 92 Cong. Rec., June 10, 1946, at 6677; Bellows, In Defense of Lobbying (1935) 172 Harrers 96. One method of instigating genuine letters was practiced by the sugar interests who procured their employees to write letters to Congress. See Thomas, My Adventures With the Sugar Lobby (1913) 26 WORLD's WORK 540. Policy holders of insurance companies have been solicited to send wires and letters to legislators at the expense of the company. BLAISDeLL, op. cil. supra note 10 , at 136 .

18. The two-party system has discouraged direct participation in politics by pressure groups, who prefer to support individual candidates from whom promises can be extracted. Consciousness on the part of political parties as to the political power of special interests has led to the addition of more and more planks in party platforms designed to attract a group vote. See Logan, supra note 10, at 80; Odegard, Political Parties and Group Pressures (1935) 179 THE ANNALS 68.

19. An examination of the testimony before almost any Congressional Committee indicates the extent of this activity. Modern legislation affects many groups in widely scattered areas and occupations. See, for example, the lobbying of coal, gas, labor (UMW), railroads, steel, and electric interests in regard to the proposed sale of the "Little-Big-Inch" pipeline, discussed in Hullinger, The Lobby's Part in Democracy (March 1946) 34 Natron's Busintss 78, 79-80.

20. The Constitutional difficulty is the applicability of the First Amendment which prohibits "abridging the freedom of speech or of the press; or the right of people . . . to 
observers today would advocate the abolition of pressure groups or forbid the activities of lobbyists. ${ }^{21}$ In addition to providing an unofficial form of functional representation, pressure group activities which publicize the legislative process, focus attention upon the voting records of congressmen, and keep the public informed as to the content and significance of legislative proposals are desirable in a democracy. The expert analysis of bills made by the competent lobbyist before congressional committees, and the link he provides between legislators and a large segment of the public may well improve the quality of legislative decision. While the larger and more cohesive the interest represented the more justification can be found for its activities, it remains true that the smallest minority has a right to be heard. It is hopeless to classify lobbies in terms of "good" or "bad", i.e., those which concern themselves with what they conceive to be the public welfare and those which work for the direct interests, usually economic, of their membership. All lobbies identify their interests with those of the general public and may, in particular situations, be justified in doing so. The danger to rational legislative decision lies not from hearing the claims of organized groups, but from inability to determine when those claims legitimately represent the welfare of the general public. This difficulty stems from the ignorance of legislators

petition the government for a redress of grievances." Although these rights are fundamental they are not absolute in nature and can be limited when the facts malie it imperative. Sse Ex parte Yarbrough, 110 U. S. 651, 665-7 (1884) (government can protect itself against "the influence of extraneous violence and internal corruption"); Burroughs and Cannon v. United States, 290 U. S. 534 (1934) (upholding analogous Corrupt Practices Act as being within congressional power). In the fifty-six years since Massachusetts enacted its lobbying law, the constitutionality of state statutes embodying similar requirements has bren attacked only once. Campbell v. Commonwealth, $229 \mathrm{Ky} .264,17 \mathrm{~S}$. W. (2d) 227 (1929) (Kentucly statute upheld on grounds of danger to government from improper lobbying and corruption).

It is not likely that the instant Act will be challenged as a violation of the right of free speech or right to petition. Although many groups have registered under protest that the Act did not apply to their activities, only one has filed notice that it considers the Act a violation of the Constitution. See Memorandum on Regulation of Lobbying Act from Thomas James Norton to Dr. Edward A. Rumely, Assistant Secretary of the Committee for Constitutional Government, September 14, 1946. In addition to abridging the right to petition, Mr. Norton contends that the filing of financial statements under the Act constitutes an illegal search and seizure prohibited by the Fourth Amendment. The fact that the Committee has registered under the Act is perhaps indicative that not even it regards the argument as persuasive.

21. This represents the almost universal view of modern commentators. But the corruption which marked the old lobby caused earlier writers to talie a contrary view. Sze Notes (1919) 23 Law Notes 3; (1922) 25 id. 223; (1923) 26 id. 222. Revelations of modern practices have occasionally evoked similar remarks from legislators and the press. Sre, for example, the speech of Senator Black on Aug. 8, 1935. "Contrary to tradition, against the public morals, and hostile to good government, the lobby has reached such a position of power that it threatens government itself. Its size, its power, its capacity for evil; its greed, trickery, deception and fraud condemn it to the death it deserves. You, the people of the United States, will not permit it to destroy you. You will destroy it." Black, Lobby Irrestigalion (1935) 1 Vital SPEECHEs 762, 765. 
amidst the growing complexity of governmental functions, the unequal power of pressure groups, and the abuses which have survived the old lobby or arisen in the new lobby.

The evils disclosed by legislative investigations of lobbying fall roughly into two categories: (1) activities which leave the public and legislators with inadequate or unbalanced information on which to make decisions; and (2) activities which coerce or corrupt legislators.

Pressure group propaganda aimed primarily at influencing the public is often characterized by misrepresentation or distortion of fact, made more effective by concealment of source. When the source of a statement is undisclosed, or appears nonpartisan, legislators and the public, ignorant of motivation, cannot evaluate possible bias. Special interests have often created a favorable climate of opinion by such questionable practices as controlling newspaper editorial policy by placement or withdrawal of advertising ${ }^{22}$ sending "canned copy" to country presses; ${ }^{23}$ hiring radio commentators and columnists to express favorable views, educators to write textbooks, and speakers to address clubs, schools, and churches without revelation of the contract of employment.

While most lobbyists openly admit their affiliations, many are prone to exaggerate the size and cohesion of their membership, and sometimes work for interests other than those they claim to represent. Oftentimes one group will serve as a "front" for another, disguising the partisan nature of the views it advocates $;^{24}$ some lobbies of this type exist on paper only. ${ }^{25}$ The forces of

22. See Hearings before a Special Commillee to Investigate Lobbying Activilies purstant to S. Res. 165 and S. Res. 184, 74th Cong., 1st Sess. (1935), pt. 3, passim. The testimony of Mr. Hopson of the Associated Gas and Electric Co. is particularly enlightening. Whether or not withdrawal of advertising is actually threatened is of minor importance. The very magnitude of the advertising expenditures is sufficient to create a friendly atmosphere in newspaper circles.

23. Such copy is often sent out in the form of "boiler plate" to small town and country newspapers. Since it is already set up in type, it can be used as an inexpensive filler. When printed it is clipped by the pressure group and sent to legislators as an indication of local editorial opinion. The American Bankers Association sends out such matter to over 6,000 newspapers with an estimated reading public of 25,000,000. BLAISDELL, op. cit. supra note 10 , at 130 . One utilities company secured the equivalent of 65,526 pages of newspaper space in this manner. Odegard, Lobbies and American Legislation (1930) 31 CuRRENT History $690,696$.

24. "If the Chamber of Commerce is the spokesman at Washington for American business, its special pleader before Government and people is the American Bar Associntion." BLAISDELL, op. cit. supra note 10, at 37. Some associations claim a wide popular base but investigation shows their financial support is not coterminous with their membership. Taxpayers Associations often derive their funds from large corporate interests.

25. "These associations include fake agricultural associations, fake scientific associations, fake religious associations, fake temperance associations, fake associations in opposition to prohibition, and, in fact, nearly every activity of the human mind has been capitalized by some grafter with 'headquarters' established for this activity in Washington. The only activity in fact engaged in is to extract money from credulous people and put into their own pockets." SEN. REP. No. 342, 70th Cong., 1st Sess. (1928) 2. The lobbying registration act 
group opinion can be magnified by instigation of letters, telegrams, and phone calls to congressmen which, though the sole creation of a special interest group, create a false impression of opinion in the legislator's home district.

Activities which coerce or corrupt congressmen are a hangover from the old lobby, and, though of lesser importance, are occasionally resorted to. Included in this category are such crude devices as bribery, threats, and promises of financial security, as well as the subtler techniques of social pressure. ${ }^{26}$

\section{Public Utrlitres-A Case Study}

The extent to which pressure groups engage in all forms of lobbying activities is well illustrated by the tremendous campaign of the public utility companies against government regulation or ownership. ${ }^{27}$ The investigation by the Federal Trade Commission in 1928-9 uncovered the expenditure of millions of dollars in a propaganda and educational program that achieved such proportions that the FTC was forced to conclude "that no campaign approaching it in magnitude has ever been conducted except possibly by governments in wartime." $2 s$

The campaign was carried on under the direction of a Joint Committee of National Utility Associations which laid down the policy for twenty-eight state utility committees. Every effort was made to win newspapers to the Utilities viewpoint and techniques included placement of huge advertising contracts, social favors to editors and entertainment of newsmen, wide distribution of pamphlets and "clip sheets." An annual expenditure of over thirty million dollars a year in advertising proved an effective weapon. Financial support to news and editorial services,, 2 without disclosure to the public, also aided in achieving general newspaper support. Articles written by state publicity directors were placed in newspapers under the names of

proposed by Senator Caraway, upon which the present Act is modeled, was aimed primarily at this type of activity. The problem is also recognized by the Joint Committee in its report to the Senate. SEN. REP. No. 1400 at 27.

26. The "social lobby" operates upon the legislator's desire to associate with the best in Washington society. No direct pressure is commonly put upon him. He is invited to the "right" parties, is wined, dined and entertained by the "right people." It is subtly suggested that he vote the "right" way. If he does not he is likely to have a dull time at the next congressional session. Its force and effect is almost impossible to estimate and it is doubtful if it is susceptible to control by any means at all. A good description of its operation can be found in CRAWFORD, op. cil. supra note 10, at $16 \mathrm{et}$ seq.

27. See SEN. Doc. No. 92, pt. 71, 70th Cong., 1st Sess. (1928) (Report of FTC on propaganda methods of public utilities); Hearings before a Special Commillec to Inrestigate Lobsying Activities, 74th Cong., 1st Sess. (1935) pt. 3. A summary of the activities can be found in BLAISDEL, op. cit. supra note 10, at 152-162.

28. SEN. Doc. No. 92, supra note 27 , at 18 .

29. Id. at 92 (listing the services). Even more direct control of the press was attained. In 1928, the International Paper Co., a subsidiary of International Paper and Power Co., secured stock control of ten important newspapers. The International Paper Co., which justified its control as a campaign for newsprint, realized over half its net income from vater power holdings as compared to roughly one third from the pulp business. Id. at 85-8. 
prominent men who had no apparent connection with utility interests.

A program of close cooperation with schools was likewise inaugurated so. as "to fix the truth about utilities in the young person's mind before incorrect notions become fixed there." 30 Friendly relations were cultivated with educators who were paid salaries during vacations to "learn the public utilities business at first hand." 31 Funds for research were made available to institutions. Textbooks representing a viewpoint favorable to utilities were introduced in public schools, and supplemented with pamphlets prepared by the state committees.

Public speakers representing the utility position made speeches before all types of audiences which were often later carried by newspapers as news stories. ${ }^{32}$ The rather narrow popular base of the group was widened and made more effective by increased sale of stock throughout the country. ${ }^{33}$

Amidst this publicity campaign highly paid Washington representatives were busy contacting congressmen and exerting pressure on influential government officials. Such activity reached its height immediately prior to the vote on the Public Utility Holding Company Act, in opposition to which the utility lobby spent over four million dollars. Ex-legislators were employed to influence their former colleagues, aid of the social lobby was enlisted, and a deluge of telegrams, sent without the knowledge or consent of the signers, ${ }^{34}$ swamped wavering congressmen. It was this latter practice that moved Congressman Driscoll to inaugurate the subsequent investigation of the lobbying activities connected with the Holding Company Bill.

Passage of the Bill did not put an end to pressure group opposition which merely shifted its primary target from legislature to courts. Literally dozens of suits were filed by utility companies alleging the unconstitutionality of the Act. ${ }^{35}$ Similarly the competition offered by government through the Tennessee Valley Authority was widely fought in the courts. ${ }^{36}$

30. Id. at 141. The Utility program for education is summarized at pp. 139-221.

31. Id. at 149.

32. ". . . matter that might be classified as strictly propaganda and thus barred from the news columns of the big dailies, actually did find its way into those papers because, being delivered by a speaker before a civic organization of standing in the community, it became news and was printed as such." $I d$. at 78.

33. Very little of this stock carried voting privileges. For example, less than $2 \%$ of the shares sold in $1925-26$ and $7 \%$ in $1924-5$ were voting shares. Sale of 10,000 shares in Alabama changed the whole tone of newspaper editorials and in California the 150,000 stockholders of the utilities were the most significant factor in defeating a state water power pro. gram. Id. at $11,307$.

34. See, for example, Hearings, supra note 27, at 1007 et seg. The holding company system spent about $\$ 134,000$ instigating these last minute telegrams and phone messages. Names were taken directly from phone directories and signed to telegrams. Discovery of fake messages may have turned the tide and made possible the passage of the bill. It passed the Senate by a single vote.

35. By agreement proceedings were stayed in all except one suit. The constitutionality of the registration provisions of the Act was upheld by the Supreme Court. Electric Bond and Share Co. v. SEC, 303 U. S. 419 (1938).

36. Tenn. Elect. Power Co. v. TVA, 306 U. S. 118 (1939). Eighteen power companies 
Today the fight against rural electrification projects goes on apace. On March 11, 1946, Speaker Rayburn called the attention of Congress to the fact that the Capitol was "seething with utility lobbyists" out to kill rural electrification and public owned power in general. ${ }^{37}$ The National Association of Electric Companies ${ }^{38}$ has spent $\$ 192,000$ on lobbying activities between August 2 and October 15, 1946. Its principal lobbyist ${ }^{20}$ receives a salary comparable to that of the President of the United States.

The methods of influencing legislation used by the Public Utilities lobby are employed to a greater or lesser extent by all national pressure groups. The problem of lobby regulation is not one of curbing the activities of a single, or even a few, special interests. It is, rather, the problem of insuring rational decision when legislators, and the public, are bombarded from all sides by the demands of hundreds of organizations. Solution to this problem does not necessarily resolve itself into a choice between suppressing such propaganda or allowing it to flourish. Exposure of lobbying activities to informed criticism through disclosure of the source of apparently disinterested statements is one method. The effectiveness of such publicity is well illustrated by the passage of the Public Utility Holding Company Act after discovery that the bulk of the opposition came from trumped-up Utility propaganda.

\section{State Regulation of Lobbying}

While the Federal Regulation of Lobbying Act represents the first federal statute passed with the end of bringing lobbying activities into the open, it has precedent in a number of state laws. In addition to the universal prohibition against giving, offering, or receiving bribes, thirty-five states have enacted statutes aimed at limiting lobbying abuses. All of these statutes, while differing in their specific provisions, proceed on the common principle that undesirable activities can best be controlled, not by prohibition, ${ }^{49}$ but by publicity.

were involved in the appeal to the Supreme Court, which dismissed the case on the theory that appellants had no standing before the court.

37. 92 Cong. Rec., March 11, 1946 at 2156. Mr. Rayburn recalled the 1935 fight over the Holding Company Act, of which he was a sponsor and continued "If they are spoiling for another brush with me . . . they can get it. . . I Ibid. The statement resulted in some agitation for another congressional investigation. See Murray, Inrestigale ite Porcer Lobby Noio (July 1, 1946) 114 New Republic 917.

38. It is alleged that about $60 \%$ of the electric companies are members of the Association. It appears to be the successor to the Edison Electric Institute, which, prior to 1933, operated under the name of the National Electric Light Association. MLurray, supra note 37, at 917 .

39. Purcell L. Smith, one-time Insull man, receives $\$ 65,000$. He is President of the $\mathrm{Na-}$ tional Association of Electric Companies. Both Mr. Smith and the Association have registered under the provisions of the Regulation of Lobbying Act.

40. But see NEB. Rev. Stat. (1913) $\S 50-301$ and S. D. CoDE (1939) $\S 55.0705$ (Limit scope of activities to appearances before committees, public addresses, newspapers, and written statements or briefs.). 
The most frequent requirements of state laws ${ }^{41}$ are (1) registration, (2) filing expense accounts, and (3) prohibition of contingent compensation. The more comprehensive laws require registration of both the individual lobbyist and his employer with a governmental agency, usually the Secretary of State. Registration statements often include, in addition to name and address, specification of the legislation promoted or opposed, but here a very general answer suffices. Several states, following the pattern of the Massachusetts statute ${ }^{42}$ make a distinction between "legislative agent" and "legislative counsel," but this differentiation appears to serve no functional Durpose.

In seventeen states the employer and lobbyist must also file detailed statements showing the amounts received and expended in promoting or opposing

41.

\begin{tabular}{|c|c|c|c|c|c|}
\hline - State & $\begin{array}{l}\text { Lares Limiled lo } \\
\text { Corrupt Praclices }\end{array}$ & $\mid \begin{array}{c}\text { Registralion } \\
\text { Required }\end{array}$ & \begin{tabular}{|l|} 
Distinclion Belsceen \\
Counsel and Agent
\end{tabular} & $\begin{array}{l}\text { Financial } \\
\text { Slatement Required }\end{array}$ & $\begin{array}{c}\text { Contingend Coma } \\
\text { pensalion Prothibiliod }\end{array}$ \\
\hline 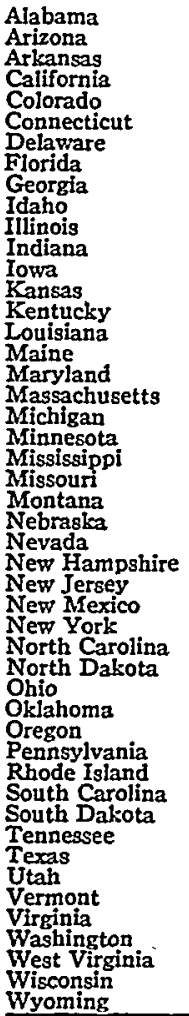 & $\begin{array}{l}x \\
x \\
x\end{array}$ & $\begin{array}{l}x \\
x \\
x \\
x \\
x \\
x \\
x \\
x \\
x \\
x \\
x \\
x \\
x \\
x \\
x \\
x \\
x \\
x \\
x \\
x \\
x \\
x \\
x \\
x \\
x \\
x \\
x \\
x\end{array}$ & $\begin{array}{l}x \\
x \\
x \\
x\end{array}$ & $\begin{array}{l}x \\
x \\
x \\
x \\
x \\
x \\
x \\
x \\
x \\
x \\
x \\
x \\
x \\
x \\
x \\
x\end{array}$ & $\begin{array}{l}x \\
x \\
x \\
x \\
x \\
x \\
x \\
x \\
x \\
x \\
x \\
x \\
x \\
x\end{array}$ \\
\hline
\end{tabular}

The table is adapted from Zeller, State Regulation of Legislative Lobbying in 5 CounciL of State Governnents, The Book of the States (1944) 161, 165-6.

42. Mass. Laws (1932) c. $3 \$ 39$. For interpretations of the statute see (1896) 10 p. ATt'y GeN. (Mass.) 311; (1912) 3 id. 469. 
legislation, including an affidavit as to the agent's salary. These expense accounts are usually submitted from one to four months after the close of the legislative session and are open to public inspection.

The frequent provision forbidding compensation which is contingent upon the success of the lobbyist in attaining the desired legislation is merely legislative condemnation of a contract which courts have long regarded as opposed to the public interest and unenforceable. ${ }^{43}$

A major weakness of all state statutes is the lack of adequate enforcement provisions. Although criminal sanctions are imposed for violation of the registration requirements, no special agency is charged with investigating either the accuracy or inclusiveness of the registration lists and financial statements. That Attorneys General have exhibited no particular desire to bring actions except in the case of flagrant violations accompanied by wide publicity is indicated by the wide variation in the number registering from state to state and year to year, and the absence of entries of large sums in expense accounts. ${ }^{44} \mathrm{~A}$ conclusion that the law is broken with impunity is inescapable. ${ }^{45}$

The failure of states to regulate pressure group activities successfully has often been attributed to lack of a specific statutory definition of "lobbying."

43. Noonan v. Gilbert, 68 F. (2d) 775 (App. D. C., 1934); Gesellschaft fur Drahtlose Telegraphie v. Brown, 78 F. (2d) 410 (App. D. C., 1935); Coquillard's Adm'r. v. Bearss, 21 Ind. 479 (1863). But courts have not always seen fit to distinguish cases where the compensation was contingent from those where it was not. The early practice was to refuse to enforce any contracts for influencing legislation. See Providence Tool Co. v. Norris, 2 Wall. 45 (U.S. 1864); Marshall v. Baltimore \& Ohio R. R., 16 How. 314 (U. S. 1853); Hazelton v. Sheckells, 202 U. S. 71 (1906). In recent years a few courts have enforced the contract when compensation was not contingent. Herrick v. Barzee, 96 Ore. 357, 190 Pac. 141 (1920); Stansell v. Roach, 147 Tenn. 183, 246 S. W. 520 (1923); Stroemer v. Van Orsdel, 74 Neb. 132, 103 N. W. 1053 (1905); Notes (1940) 15 IND. L. J. 230; (1933) 12 TEx. L. REv. 85; (1934) 14 Bost. U. L. REv. 334; (1922) 7 CoRN. L. Q. 361. It is questionable if there is any functional basis for the distinction between the two types of lobbying contracts. It is more likely that courts denouncing lobbyists have thought in terms of the corrupt practices of the old lobby, while courts recognizing the less reprehensible lobbying of more recent times as a legitimate occupation have sought a ground for differentiation in the fact of contingent compensation.

44. In 1941 registrations varied from four in Georgia to 950 in Wisconsin. Zeller, supra note 41 , at 163. Professor Zeller's study of New York pressure groups revealed a total of only $\$ 103,796$ (exclusive of lobbyists' salaries) spent in 1935 according to registration statements. Registrations over the preceding ten years varied from 75 to 145. Many of the groups registering failed to file expense statements. ZELLER, op. cil. sttpra note 10, at 254-6. An earlier study of state registrations revealed that in Ohio all the expense accounts filed bore the same legend "received nothing and spent nothing." Pollock, The Regulation of Lobbying (1927) 21 Axr. PoL. Scr. Rev. 335, 339. See also, Zinl, Indiana Lobby-Contro? Found Insufficient (1938) 27 Nar. Munic. Rev. 543.

45. The only state which seems to have been at all successful with lobbying legislation is Wisconsin, where registrations always exceed those of other states. The Wisconsin statute is not significantly different from other legislation, and Wisconsin does not appear to have convicted any offenders. Annotations to state statutes indicate that there have been no appeals from conviction under anti-lobbying laws. 
Legislators drawing up state laws appear to regard lobbying as limited to the old methods of face-to-face persuasion with its accompanying graft and corruption, and give inadequate consideration to modern propaganda and publicity techniques. Even the most comprehensive laws emphasize the activities of the lobbyist rather than the pressure group he represents. This interpretation is most clearly indicated when statutes use such expressions as "to personally influence," 46 "privately or secretly attempt to influence," 47 or "improperly influence" 48 to define lobbying practices. Not only the phraseology of the acts but their total divorcement from such analagous problems as corrupt election practices, improvement of legislative information services, and functional representation indicate that these statutes were directed at what was conceived to be an isolated evil which needed regulation. The failure, therefore, lies not merely in the inadequacy of statutory language, but in the more basic fault of which lack of precise definition is a manifestation: the inability of state legislatures to see pressure group regulation in its relation to the whole decision-making process.

\section{Provisions OF THE ACT}

\section{Legislative Background:}

Just as the impetus to state legislation came from the disclosures of the Armstrong Committee's investigation of New York insurance companies in 1905-6, the most serious attempts at federal regulation have followed revelation of lobbying activities by the N.A.M. in 1913 on proposed tariff legislation, ${ }^{49}$ and by the public utilities in 1928 and $1936 .{ }^{50}$ Bills introduced by Senator Caraway ${ }^{51}$ in 1928 and Senator Black ${ }^{52}$ and Representative Smith ${ }^{60}$ in 1936 passed their respective houses but did not meet with the approval of Congress. Their failure of passage has usually been ascribed to congressional fear of interference with the constitutional right to petition and opposition of lobbyists to registration requirements. To this might be added a belief by congressmen that they are not susceptible to group pressures.

46. IDAHO CODE ANN. (1932) §17-607.

47. LA. GEN. Stat. ANN. (Dart, 1939) § 9279.

48. Cat. Penal Code (Deering, 1941) §89.

49. Denunciation of lobbying activities in connection with the tariff by President Wilson led to investigations by both the Senate and the House. The Senate Committee did not file a report although several volumes of testimony were taken. One member of the House was censured for "grave acts of improper influence" but no direct corruption was proven. See H. R. REP. No. 113, 63rd Cong., 2nd Sess. (1913).

50. See note 27 supra.

51. S. 1095, 70th Cong., 1st Sess. (1928). The bill was reported out of committee after accusations on the floor of the Senate of public utility lobbying in connection with the Walsh resolution to investigate public utility financing. See 69 CoNG. REc. 2893-4 (1928).

52. S. 2512, 74th Cong., 2nd Sess. (1936). The text of the bill can be found in 80 Cong. Rec. 4970 (1936).

53. H. R. 11663, 74th Cong., 2nd Sess. (1936). The text of the bill can be found in 80 Cong. Rec. 4533-41 (1936). 
The report of the House committee in 1913 defined lobbying as the "activities of a person or body of persons seeking to influence Congress in any way whatever" 54 and this broad definition has been incorporated directly or indirectly in subsequent bills. But despite the broad possibilities of such a definition, none of the afore-mentioned legislative proposals showed any attempt to deviate from the rather narrow conceptions embodied in state statutes. The Caraway, Black, and Smith bills focused their attention upon the activities of the Washington representatives rather than the pressure groups themselves, and were particularly concerned about the lobbying of specious organizations. ${ }^{55}$ Senator Black's investigation of airmail contracts prompted him to expand the Caraway proposals to include lobbying before administrative agencies. ${ }^{56}$

Although the wording of the 1946 Act is almost identical with that of its predecessors, there is evidence that the views of the present Congress toward lobbying are significantly broader than those of the past. The Act studiously avoids use of the word "lobbying" and the committee reports refer to the activities of "pressure groups" and their "agents," emphasis being given to the activities of the former. ${ }^{57}$ The unfortunate identity of language between the instant Act and the Black and Smith bills is not solely explicable in terms of congressional intent; it is attributable largely to the speed which marked the drafting of the Reorganization Act, ${ }^{63}$ the indifference with which legisla-

54. H. R. REP. No. 113, 63rd Cong., 2nd Sess. (1913) 15.

55. See note 25 supra. It is likewise apparent that Senator Blacls saw registration of lobbyists largely as a device to cure improper lobbying practices. Hearings bafore a Subcommittee of the Committee on the Judiciary on S. 2512, 74th Cong., 1st Sess. (1935) 14-5.

56. The Black Bill proposed that lobbyists before the legislature register with the Clerk of the House and the Secretary of the Senate and those before administrative agencies with the Federal Trade Commission.

57. Sen. Rep. No. 1011, 26-7; SEN. Rep. No. 1400, 4-5. The Act was intended to include three types of lobbyists: (1) "Those who do not visit the Capitol but initiate prop3ganda from all over the country. . . (2) ". . . those who are employed to come to the Capitol under the false impression that they exert some powerful influence over Members of Congress." (3) ". . . entirely honest and respectable representatives of business, professional, and philanthropic organizations who come to Washington openly and frankly to express their views for or against legislation, ...." Id. at 27.

But the importance of clever Washington representatives with the "right contacts" should not be underestimated. On August 21, 1929, William B. Shearer filed a complaint to recover $\$ 257,655$ due him from three American shipbuilders for lobbying activities. $\mathrm{He}$ contended that eight cruisers were built as the result of his efforts. Odegard, suppra note 23 at 690 . The ethics of such representatives is sometimes questionable even when no bribery is shown to exist. When Senator Black's Committee to investigate airmail and ocean mail contracts subpoenaed certain records, the Washington lobbyist and lawyer for the airlines, William P. McCracken Jr. destroyed them. Despite conviction on a contempt charge, Mr. McCracken lost no prestige in the eyes of the air line operators or the bar association. See CRAWFORD, op. cit. supra note 10, at 158-9.

58. The Act was drawn up by the Office of Legislative Counsel.The Joint Committee wished congressional action before adjournment and a minimum of time was devoted to drafting the Act. The only indication of congressional intent given the Office was the brief description provided by the Committee's recommendations as shown in Senate Report 1011. 
tors regarded the lobbying provisions, and the political expediency of avoiding too sharp a break from past attempts.

The clearest indication that the Lobbying Act represents a more mature congressional view of the pressure group problem is provided by its enactment as part of the Reorganization Act. The fact that it does not come as the result of demand for restrictive regulation following an expose by a congressional committee is further proof that Congress intended more than elimination of some of the more obvious abuses of the right to petition. A proper evaluation of the Act can only be made if it is regarded as an initial step toward solution of the problem of fitting the activities of organized groups into existing patterns of government.

The structure of the Lobbying Act indicates its composite origin. Section 308 , a slightly modified version of the Black Bill, relates to the activities of those engaged in lobbying for pay. Sections 303,304, and 305, modeled after the Smith proposal, cover the financing of lobbying through solicitation of contributions, or expenditure of funds, to influence legislation. Section 307, also from the Smith Bill, is a catch-all provision defining persons to whom the Act applies.

As in the analogous state statutes, the law establishes requirements for registration and provides for public disclosure of pressure group activities. But the vagueness of its provisions and the absence of any attempt to define directly the activities it seeks to regulate has led to much confusion as to who must register or file financial statements under the terms of the Act. The refusal of the Attorney General ${ }^{59}$ to render an official interpretation has left individuals and organizations the obligation of deciding for themselves whether or not the law is applicable to them.

\section{Registration of Professional Lobbyists:}

Section 308(a) provides that "Any person who shall engage himself for pay or for any consideration for the purpose of attempting to influence the passage or defeat of any legislation ... . shall, before doing anything in furtherance of such object, register with the Clerk of the House of Representatives and the Secretary of the Senate. ..." Although "person" is defined elsewhere ${ }^{60}$ to include both individuals and groups, it seems clear that this section refers primarily to the individual lobbyist or legislative agent.

Certain exceptions to this provision should be noted. It does not apply to (1) persons who merely appear before a committee and "engage in no other activities to influence legislation"; (2) public officials acting in their official capacity; (3) newspapermen "acting in the regular course of business"; and

The Black Bill presented a convenient model and was, therefore, utilized. Communication to Yale LAW Journal from Charles F. Boots, Office of Legislative Counsel, October 18, 1946.

59. See 31 UnIted States News (Sept. 6, 1946) 70.

60. Section 302 (c). 
(4) persons now required to report under the provisions of the Corrupt Practices Act. ${ }^{61}$

Construed by itself, Section 308 sets up two conditions which must be satisfied before a person need register; he must be employed by another for a valuable consideration, and the purpose of the employment must be to influence legislation. But a difficulty arises as to whether this section, as well as the section which requires the organization to file an expense account, can be read alone or must be construed in the light of Section 307 which reads, in part, as follows:

"The provisions of this title shall apply to any person who ... . directly or indirectly solicits, collects, or receives money or any other thing of value to be used principally to aid, or the principal purpose of which person is to aid, in the accomplishment of any of the following purposes:

(a) The passage or defeat of any legislation by the Congress of the United States.

(b) To influence, directly or indirectly, the passage or defeat of any legislation by the Congress of the United States." (Emphasis sủpplied.)

An interpretation of the Act which regards this section as qualifying all others would appear to have the support of legislative intent. On the floor of the House it was referred to by a member of the Committee as containing "the gist of the antilobbying provision." 62 Furthermore, unless this section is read literally as restricting the application of the Act, the phraseology in italics above is surplusage and serves no useful purpose.

The superimposition of the language of Section 307 upon that of 308 leaves a third condition which must be fulfilled before registration is required: not only must the person be engaged for pay to influence legislation, but this must also be his principal activity. Although it is probable that most of the professional lobbyists in Washington could meet all three of these conditions and be required to register, there are at least three fairly common fact situations which may cause difficulty.

The first, and quantitatively the most important, of these situations is the case of the Washington lawyer, or law firm, who is retained by a special interest group or corporation to advise on pending legislation, render opinions as to its effect and construction, and possibly to draft bills which the group will submit to Congress. This work may be part of a large law practice.

The second situation is that of the officer of a corporation whose general duties have no reference to legislative matters but who comes to Washington to oppose a specific bill which may adversely affect the interests of his firm.

61. A list of exceptions is given in SEN. REP. No. 1400 at 26. The fact that the language of exclusion in section 308 does not include radio commentators within the general exemption given to the press raises the possibility that some broadeasters will have to register. Up until October 15, 1946, no radio commentators had registered.

62. See Remarks of Representative Dirksen in 92 Cong. Rec., July 25, 1946, at 10138. 
He speaks to congressmen, testifies before committees, and distributes literature. Immediately after the passage or defeat of the bill he returns to his usual duties.

The third problem is that presented by the member of a group who comes to Washington to testify before a committee, distributes literature to congressmen, and takes his local Representative to dinner. The group pays his expenses but nothing more.

It is probable that the lawyer would not have to register. Although the phrase "influencing legislation" is a broad one, it is not within the legislative intent to include activities of counsel who merely perform advisory functions. ${ }^{63}$

The corporate officer would, on the other hand, have to register before he undertook to engage in such typical lobbying activities. He might, of course, argue that he was not employed to influence legislation and that this was not his principal activity. But it is reasonable to assume that at least part of his corporate duties are of this nature and thus part of his compensation is derived for such activities. He is acting in his official capacity and not as an individual since it is the interests of the corporation which are affected by the pending legislation. Likewise, it is apparent that the word "principal" can be defined only if given a time reference. Although over a long period of time his principal activity may be with other corporate affairs, nevertheless his principal activity during his Washington stay is representing the corporate interest before legislators. ${ }^{64}$ This same rationale would apply to the lawyer in the first example if he went beyond interpreting legislation and approached congressmen, or if he himself submitted the drafted bill to a member of the legislature.

The representative of the interest group in the third illustration would not have to register. Although he meets the requirements of "influencing legislation" and "principal activity," he is not engaged for pay. The intent of Congress was not to limit in any way the individual's right to petition and was aimed only at professional lobbyists. ${ }^{65}$ If the compensation were merely actual expenses, it would not meet this test of employment for consideration, but if the sum given should substantially exceed expenses, he would have to register.

It may be difficult in any given case to determine just what constitutes

63. Many state statutes specifically exempt lawyers who do not personally approach legislators and confine their activities to interpreting and analyzing legislative proposals. Even in the absence of statutory exemption analogous state laws have been deemed inapplicable to attorneys engaged in a purely advisory capacity. See (1937) 26 Or. Atr'y GeN. (Wisc.) 183-4.

64. Analogous provisions of the Caraway and Smith bills have been interpreted by legislators to this effect. See 69 Cong. REc. 3932 (1928); 80 CoNG. REC. 4521 (1936). Furthermore, such interpretation has been given to state statutes. See (1937) RER. ATr'Y GEN. (Mass.) 59-60; (1915) 1 Op. Atr'x. Gen. (Ohio) 41.

65. See 92 Cong. Rec., June 10, 1946, at 6676-8. A similar provision in the New York statute has been interpreted to this effect. (1939) REP. ATT'y GEN. (N. Y.) 233-4. 
"influencing legislation." 66 The Act is indefinite in this respect and, since criminal statutes must define prohibited acts with certainty, this indefiniteness might make it technically defective. It is more likely, however, that courts will construe the provision strictly and require proof of actual intent on the part of an organization or individual to promote or defeat passage of a definite legislative proposal. Sufficient intent might, for example, be indicated by the presence of a legislative program endorsed and advocated by the group or its representative.

\section{Filing of Expense Accounts:}

A. By the Lobbyist:

Every person who registers under Section 308 is required to file in addition to the registration form a detailed report under oath of all money received and expended by him during the preceding calendar quarter. ${ }^{17}$ The report includes a statement identifying the person paid, the purposes for which the money was expended, and the legislation he is paid to support or oppose. He also must state the names of any papers or periodicals in which he has caused editorial or news matter to be published.

\section{B. By the group or organization:}

Section 305(a) provides that "Every person receiving any contributions or expending any money" to influence legislation must file a detailed statement every calendar quarter with the Clerk of the House. The term "person" again is defined to include any individual or group of persons, corporation, partnership or association, but excludes anyone registering under the Corrupt Practices Act. ${ }^{6 s}$

66. A literal interpretation of the Act might well result in fantastic requirements, which, through the bulk of registrations, would only destroy its already feeble publicity provisions. Technically an agency which placed advertising in newspapers might be required to register, together with the person who composed the advertisement and the corporate officer in charge of public relations. Political science professors at educational institutions might be construed to be indirectly influencing legislation through their critiques of existing laws. Such unrealistic interpretations are to a great extent limited by construction of the Act to require that it be a "principal" activity. Since it was the congressional intent to require registration by those who are commonly designated "professional lobbyists" it would seem that the language used is unfortunately broad. There seems no reason why this provision should not be limited to persons directly approaching Congressmen for the purpose of defeating or promoting legislation. The activities of other individuals would be included in the expense accounts of the organization filing under $\S 305$.

67. This would include sums spent in entertaining congressmen, buying them meals or giving dinners in their honor. Such an interpretation is supported by Senator Black's analysis of his bill which employs the same language as the instant Act. See Hearings lefore a Subcommittee of the Conmittee of the Judiciary on S. 2512, 74th Cong., 1st Sess. (1935) 12-3.

68. A literal interpretation of the language of section 305 would require compliance of the professional lobbyists who register under section 308 with this provision as well. Since the information required here is substantially the same as required under section 305 , such a 
As in the case of individual lobbyists the provisions of Section 305 are limited by Section 307.69 Thus construed, only those organizations which solicit money or receive contributions principally to aid in the influencing of legislation, or those receiving or expending money whose principal purpose is to influence, directly or indirectly, legislation must register.$^{70}$ Obviously the efficacy of the provision hinges on judicial interpretation of the word "principal."

Past congressional investigations have disclosed the fact that the most important pressure groups today are the National Association of Manufacturers, the Chamber of Commerce, the $\mathrm{AF}$ of $\mathrm{L}$, the $\mathrm{CIO}$, various trade and professional associations,. labor groups, farm associations, and veterans' organizations. All of these special interests could argue that their principal activity is dissemination of information within the group for business or social purposes, trade promotion, or research, and that their lobbying activities, however extensive, are not the principal purpose of the organization. ${ }^{71}$ Such an interpretation would completely emasculate the Act; almost no group which exercises a substantial influence over public or legislative opinion would be required to register. Groups spending hundreds of thousands of dollars in propaganda activities would be exempt from reporting such expenditures, while other groups spending only insignificant sums would have to submit detailed accounts.

Despite the fact that a literal interpretation of "principal" makes little sense in the light of the factual situation, a strong argument to support this

construction would appear unnecessarily strict. The seeming double coverage serves to emphasize the unfortunate looseness and ambiguity of the provisions of the Act.

There is, however, the possibility that persons who would register under section 308 except for the exclusionary language might have to register under section 305 if they met its requirements. Here there would be no problem of duplicate filing.

69. If this limitation is not applied, section 305 would become so comprehensive as to lead to absurd results. Any person receiving any contributions or expending any money to influence legislation would include, for example, not only a pressure group, but every individual contributor as well as any person mailing a letter or sending a telegram to his congressman.

70. One other possible construction should be noted. Section 307 could be construed as making solicitation, collection or receipt of money the essential factor. In this case only persons soliciting, collecting or receiving money would register, and then only if the money is used principally to influence legislation, or if lobbying is the principal purpose of such person.

71. In debate on the floor Senator Hawkes (N. J.) asked Senator LaFollette if the Act would require registration by the Chamber of Commerce. When he reccived a non-commital answer he expressed the opinion that organizations of this type would be excluded by tho "principal" requirement. He was not supported in this interpretation by the sponsors of the bill. Despite Senator LaFollette's assurance that no stigma was attached to registration, Senator Hawkes persisted in regarding it as a penalty. See 92 Cong. Rec., July 26, 1946, at 10286-87. Commentators have expressed the opinion that the Chamber of Commerce and labor unions would have to register under the analogous provisions of the Black Bill. Mechn. ling, supra note 13, at 329. Senator Hawkes is a former President of the Chamber of Commerce. 
view can be made from the legislative history of Section 307. The Smith Bill, from which the section was copied almost verbatim, originally used the phraseology "in whole or in part," and its sponsor substituted the word "principally" when the breadth of the former provision was brought to his attention. When asked whether labor and fraternal organizations would have to register, Representative Smith replied in the negative. He stated that the provision was intended to exclude many large organizations with thousands and millions of members who spent only a minor part of their funds influencing legislation. ${ }^{72}$

In debate on the instant Act it was stated that the groups which were included in this section were "those whose principal purpose, not incidental purpose" was "to influence the passage of legislation." 73 Juxtaposition of the words "principal" and "incidental" indicates that all purposes of an organization which are not "incidental" are in the category covered by the Act, suggesting a much broader meaning of the word "principal" than it might be given if taken alone.

A classification of activities which only incidentally influence legislation can be found in cases construing provisions of the Internal Revenue Code. ${ }^{74}$ Tax exemption is provided for gifts to charitable and educational organizations "no substantial part of the activities of which is . . . attempting to influence legislation." The test imposed by the courts has been whether or not the political activity is incidental to the main purposes of the organization, ${ }^{75}$ and relevant criteria include its stated purpose as determined by the articles of association, ${ }^{76}$ the amount expended in political activities as contrasted with other business, ${ }^{77}$ the presence or absence of a political program, ${ }^{78}$

72. See 80 CoNg. Rec. 4535,9752 (1936).

73. "What we are trying to do here is to reach those whose principal purpose, not incidental purpose, but whose principal purpose is to come here and endeavor to influence the passage of legislation either by bringing about its defeat or its enactment." 92 Cong. Rec., July 25,1916 , at 10138 . The statement was made by Representative Dirlsen, a member of the committee. See also SEN. REP. No. 1400, 27 (". . . does not apply to organizations formed for other purposes whose efforts to influence legislation are merely incidental to the purposes for which formed."). This portion of the Senate report was taken directly from remarks by Representative Smith on the floor of the House in 1936. See 80 Cosc. REc. 9751 (1936).

74. INT. REv. CODE $\$ \$ 23$ (0) (2), $\$ 12$ (d). 1004 (a) (2) (B). These sections codify a long standing Treasury Regulation employing the same language.

75. A leading case also employs the language "mediate to the primary" purpese" and "ancillary to the end in chief." Slee v. Commissioner, 42 F. (2d) 84,185 (C. C. A. 2nd, 1930). See also Old Colony Trust Co. v. Welch, 25 F. Supp. 45,49 (D. Mrss. 1938 ).

76. Leubuscher v. Commissioner, 54 F. (2d) 998 (C. C. A. 2d, 1932) (bequest to MIanhattan Single Tax Club taxable); Joseph M. Price, 12 B. T. A. 1186 (1928) (contribution to City Club of New York held taxable).

77. Girard Trust Co. v. Commissioner, 122 F. (2d) 108 (C. C. A. 3rd, 1941); Faulliner v. Commissioner, 112 F. (2d) 987 (C. C. A. 1st, 1940); Charles W. Dahlinger, 20 B. T. A. 176 (1930).

78. Weyl v. Commissioner, 48 F. (2d) 811 (C. C. A. 2nd, 1931); James J. Forstall, 
and the controversial nature of the propaganda promulgated. ${ }^{79}$ Under these rules gifts to trade associations, labor unions, professional groups, and social reform organizations have been deemed taxable. ${ }^{80}$ Although the analogy of the instant problem to taxation is far from perfect, neither the classification of groups nor the criteria imposed seem entirely inapposite.

If a test case should bring Section 307 before the courts for judicial construction, any one of three results is possible. The court could construe "principal" narrowly to mean "primary," "chief" or "most important." Although this interpretation would exempt most pressure groups and vitiate the Act it would, nevertheless, have the support of Representative Smith's remarks, coupled with legal dogma requiring a strict construction of criminal statutes. Where, as in the case of the typical trade association or labor union, more than one activity is engaged in, the burden of proof upon the government to establish lobbying as the most important activity would seem to preclude many convictions. Exactly what the government would have to prove, assuming the difficulties of obtaining evidence were overcome, is largely a matter of conjecture; if the objective test of comparison of sums spent on lobbying with sums spent on other activities were adopted, would it be necessary to prove that more was expended on lobbying than any other activity or than all other activities, and over what period of time would it be necessary to compare such expenditures?

An interpretation of "principal" to mean "substantial," or any activity not purely "incidental," would overcome most of the objections to which the narrower construction is subject and has already proved workable in tax cases. While the problem of the correct time reference would still be present, the breadth of activities included would make it factually insignificant. Furthermore, this interpretation is the only one which appears reasonable in the light of the pressure group problem as apparently understood by the present Congress.

The third possible result of litigation would be a holding that Section 307 is so vague and indefinite as to require invalidation of the Act. ${ }^{81}$ There is

29 B. T. A. 428 (1933); John H. Watson, Jr., 27 B. T. A. 463 (1932); Frederic C. Leubuscher, .21 B. T. A. 1022 (1930); Appeal of Herbert E. Fales, 9 B. T. A. 828 (1927).

79. Leubuscher v. Commissioner; 54 F. (2d) 998 (C. C. A. 2nd, 1932); Henriette T. Noyes, 31 B. T. A. 121 (1934); J. Noah H. Slee, 15 B. T. A. 710 (1929).

80. A list of organizations subject to, or exempt from, the tax can be found in 5 MERtENS, LAW of FED. Income Taxation (1942) $\S \$ 31.14-31.31$. See also Note (1942) 138 A. L. R. 456.

81. A similar use of the word "principally" in defining a wholesale produce dealer as one who sold principally to others than consumers was held invalid for indefiniteness by a Wisconsin court. That court was particularly concerned over the fact that no provision was made for an average period of activity against which a test could be applied. State $e x+c l$. Hickey v. Levitan, 190 Wis. 646, 210 N. W. 111 (1926). See also United States v. Petrillo, (N. D. Ill. Dec. 2, 1946) (holding Lea Act unconstitutional because phrase "needed by such licensee to perform actual services" was so vague as to violate due process clause of the Fifth amendment). 
little practical difference in a strict interpretation of the rord "principal" and a holding that Section 307 violates the Constitution; in either case the operative effect of the Act would be negligible.

It should be noted that there is no interrelation between those who file statements under Section 305 and those who register under Section 308 as is common in state statutes. Thus, it is possible for an individual lobbyist to name an employer who need not file under Section $305 .^{82}$ But if liberal interpretation is given to the word "principal," the correlation between the two lists should be high.

The quarterly statement of the group filed under Section 305 includes the name and address of all who contribute over $\$ 500$, the total sum of all contributions and the total expenditures including the name and address of those who receive an aggregate of ten dollars or more. Further provisions ${ }^{82}$ require that detailed accounts of contributions and expenditures be kept and preserved for at least two years.

\section{Enforcement.}

Violations of any provisions of the Act are punishable by a fine not exceeding $\$ 5000$ and imprisonment for not more than twelve months. ${ }^{84}$ In addition, conviction automatically disqualifies a person from attempting to influence legislation or testifying before a committee for three years with more severe penalties provided for violation of this provision. Although this latter sanction appears to be directed at the individuals registering under Section 308, the broad statutory definition of "person" makes it applicable to associations and groups as well. How it could be enforced against the latter is not clear, and in any event it could scarcely bind the individual members of a group without deprivation of their constitutional rights.

\section{The Requirements of an Effective Lobbytng Statute}

The inadequacies of the Regulation of Lobbying Act are in large measure attributable to the fact that despite evidence of a new and realistic congressional understanding of the problems raised by pressure group activity, the statutory vehicle for expression of its ideas was hurriedly drafted and modeled on anachronistic precedent. That the federal statute will be little more successful than its state counterparts is already indicated by the number of individuals and groups complying with its provisions. During the first quarter 36 organizations and 124 individuals filed statements under Sections 305 and 308 . Only three important pressure groups complied with

82. This was also the interpretation of a member of the Joint Committee. See 92 Cong. Rec., July 25, 1946, at 10138.

83. Sections $303,301,306$. The speed with which the bill was drafted and the lack of attention given to its language are illustrated by the use in $\S 304$ of the passive rather than active voice so as to make the section technically meaningless.

84. Section 310 . 
Section 305 , others apparently relying on exemption by virtue of the "principal" requirement. ${ }^{85}$

The most obvious weaknesses of the Act are the use of the word "principal" to restrict persons to whom the Act is applicable and the lack of adequate enforcement provisions. Such powerful pressure groups as the Chamber of Commerce and the NAM are construing the word narrowly and maintain that their principal purposes are trade promotion, education and research. ${ }^{86}$ Failure to submit accounts to the Clerk of the House indicates that most trade associations and labor organizations are adopting the same view. Although a test case might possibly result in an interpretation which would force their compliance, it would be preferable to amend the law so as to include all organizations which spend more than a specified sum influencing legislation.

Failure to provide sanctions to overcome the procedural difficulty of criminally prosecuting- unincorporated associations is an elementary drafting error ${ }^{87}$ which may seriously weaken the punitive provisions of the Act. As a consequence it is questionable ${ }^{88}$ whether a large proportion of pressure groups could be nade subject to its penalties, a shortcoming best cured by providing that all expense accounts be signed by a responsible executive who is personally liable for violation. If no expense account is submitted, the officers of the association should be held.

The enforcement difficulties of the Act, however, are more extensive than those embodied in a mere technical drafting error. The Department of Justice will undertake prosecution of violators of the Act only when a violation

85. The important groups registering, with their total expenses, were as follows: National Association of Electric Companies (\$192,000); American Medical Association (\$19,000); National Home and Property Owners Association $(\$ 87,000)$. All of these groups have recently been in the limelight as a result of their lobbying activities. Lobbying by public utilities was denounced during the last congressional session by Speaker Rayburn, that of the Medical Association by Senator Murray, and that of the real estate lobby by President Truman.

The small number of individual registrants is explicable in view of the congressional recess and the lack of opportunity to approach legislators. Average salaries of those who have registered are from $\$ 5000$ to $\$ 7000$, highest being that of Smith (public utilities) with $\$ 65,000$, not all of which was for utility lobbying. Expense allowances varied from "unlimited" (Smith) to "none," "actual" expenses being the most frequent entry.

86. Memorandum prepared by the Chamber of Commerce of the United States, Wash. ington, D. C., August 28, 1946.

87. The same error was made in drafting analogous provisions in the Foreign Agents Registration Act of 1938. 52 Stax. 631 (1938), 22 U. S. C. $\S 611$ (Supp. 1941-1946). This weakness was pointed out by the Institute of Living Law. See 87 CoNG. REc. Arp. A4417 (1941). The loophole was closed by the McKellar-Sumner amendment in 1942. Officers and directors were made personally liable for failure to file expense statements. 56 STAT. 256 (1942), 22 U.S. C. $\$ 617$ (Supp. 1941-1946).

88. But see Clark, J., concurring in United States v. Local 807 of International Brotherhood of Teamsters, 118 F. (2d) 684,688 (C. C. A. 2nd, 1941) aff'd 315 U. S. 521 (1942) (unincorporated associations may be subject to criminal prosecution where that is legislative intent). 
is brought to its attention. The absence of provision for a special agency to investigate the activities of lobbyists has always meant non-compliance with state laws; there is no reason to believe that there will be a significant difference in the case of a federal statute.

One of the principal reasons for requiring registration of professional lobbyists was to reveal, in addition to their identity, the size and cohesion of the groups they claimed to represent. Such knowledge is indispensable to legislators seeking to evaluate the political force of divergent views. To this end the Senate Report recommended that the registration statement include evidence of bonafide membership $;^{89}$ but this provision was never embodied in the bill as submitted to Congress. Not only should this information be required but it should be supplemented by a statement as to how the membership decides its lobbying policy and by what right the lobbyist speaks for the group. Democratic procedures within the group itself are necessary if lobbying activities are to be regarded as a legitimate manifestation of a functional need..$^{90}$

The instant Act confines itself to persons who exert pressure on Congress. The decline of Congress as a policy making body and the increased discretion exercised by administrative bodies have, however, effected a parallel shift in lobbying activities. No adequate law can ignore the pressures upon all branches of government, and registration of all those who lobby before governmental agencies should be included within the provisions of the Act."

\section{The need for a specific enforcement agency:}

Evolution of lobbying methods has made regulation of pressure groups primarily a problem in propaganda control. Control by either quantitative

89. SEN. REP. No. 1011 at 27. The statement as to the "bona fide total memberahip" of organizations was apparently left out of the Act by mere oversight in drafting attributable to the fact that it was copied from the corresponding section of the Blacls Bill.

90. See Statement of George Smith, Hearings before the Joint Commillce on the Orgarization of Congress pursuant to $H$. Con. Res. 18, 79 th Cong., 1st Sess. (1945) 411. The same opinion has been stated by John Thomas Taylor, legislative agent of the American Legion. Colonel Taylor has publicly supported the bill, but feels that its many loopholes malse it an inadequate solution to the problem of lobbying. In addition to the vealinecses already enumerated, he points out that the "social lobby" remains uncontrolled, that government officials often lobby for bills with which they have no official connection, that a lobbyist could screen his activities by becoming a precinct committeeman of a political party (and thus subject to Corrupt Practices Act), and that contributions can be broken down to sums less than $\$ 500$ and not recorded on the statement filed. Communication to XaLE Law JouRnal, November 12, 1946.

91. The provisions of the Black Bill which provided for registration of lobbyists tefore administrative agencies with the FTC may have been left out of the instant Act breause the Joint Committee was concerned with improvement of congressional procedures cnly. It may have felt such a provision was beyond the pale of congressional reorganization. The broad definition of "legislation" given by $\$ 302$ might male possible an interpretation including such activities, but this construction would find little support in terms of congressional intent. 
or qualitative suppression of political propaganda has never achieved success in the United States. ${ }^{22}$ Furthermore, it runs counter to democratic theory, made explicit in the First Amendment, that free discussion best promotes the informed public opinion necessary to rational legislative decision. But informed public opinion presupposes knowledge of all the facts, including any personal interest and bias on the part of the speaker. The force of partisan propaganda can be effectively diminished by revelation of its source and exposure to informed public criticism. This theory underlies lobby registration; the publicity principle ${ }^{93}$ is embodied in the fact that all records are open to public inspection.

The publicity given to pressure group activities by the Act is more illusion than reality. Even if the loopholes in the registration provisions were plugged by amendment and additional pertinent information required, it is improbable that the Act would accomplish much toward mitigating the evils presently existing. Operation of the publicity principle requires that actual awareness of the extent of pressure group activities be known both to legislators and the public. The Lobbying Act depends upon the fact that the information is open to the public coupled with its publication in the Congressional Record to counteract the publicity methods of groups which use every possible communication outlet to propagate their viewpoints. Furthermore, the most important information from the public's point of view, that revealed by the group's financial statement, does not even get the limited circulation of the Record.

Examination of operation of the publicity principle under the analagous provisions of the Corrupt Practices Act, ${ }^{94}$ the Voorhis Act ${ }^{95}$ and the Foreign

92. The provisions of the Corrupt Practices Acts, which limit campaign expenditures and contributions to political committees, have been consistently evaded. See PoLlock, Party Camsaign Funds (1926) c. 8; Overacker, Presidential Campaign Funds, 1944 (1945) 39 Arr. Pol. Scr. REv. 899; Comment (1945) 44 MrCr. L. Rev. 294. The Senate and House committees investigating operation of the Federal Act in 1944 came to the conclusion that the imposition of ceilings on expenditures was not an effective regulation and that publicity was the only workable solution. They reported, however, that the present publicity provisions were entirely inadequate. SEN. REP. No. 101, 79th Cong., 1st Sess. (1945) 80-2; H. R. REP. No. 2093, 78th Cong., 2nd Sess. (1945) 12.

93. See Institute of Living Law, Combating Totalitarian Propaganda: The Method of Exposure (1943) 10 U. of CEI. L. REv. 107; Smith, Democratic Control of Propaganda through Registration and Disclosure I (1942) 6 PUBLIC OPINION QUARTERLY 27, id. II (1943) 7id.707.

94. 43 STAT. 1070 (1925), 2 U.S. C. $\$ 241$ and 18 U. S. C. $\$ 208$ (1940). The registration provisions of the Lobbying Act are almost identical to those of the Corrupt Practices Act. In both instances statements are filed with the Clerk of the House and the Secretary of the Senate. In view of the conclusions of the Senate and House committees in 1944 that such publicity is inadequate to inform the public of election practices, it would seem improbablo that it will prove sufficient in the case of lobbying.

95. 54 STAT. 1201,18 U. S. C. $\S 14$ (1940). The Act, requiring registration of subvergive organizations, was never complied with, but its full and complete registration provisions might well serve as a model of the kind of information which could be required of lobbyists. 
Agents Registration Act ${ }^{96}$ leaves no doubt that some positive steps to secure circulation of the information revealed on registration statements and financial records is necessary if the Act is to accomplish its objectives. Although registration of foreign agents was reasonably complete, no effort to turn the "pitiless spotlight of publicity" upon their propaganda was made. Administration by the State Department was so inept that it was transferred to a special division of the Justice Department, where information submitted was analyzed by experts and efficiently filed. ${ }^{97}$

Special committees of the House and Senate appointed to investigate operation of the Corrupt Practices Act came to the conclusion that the analogous publicity provisions of that Act had not yet been made effective. ${ }^{83}$ Specific criticisms included the lack of a single central office with power to develop a uniform accounting system and render data intelligible to the public, as well as the lack of concern of officials over failure to file the requisite forms. Both committees, however, felt that disclosure could be made an operative regulatory device.

It is clear that neither the Clerk of the House nor the Senate Secretary has the administrative organization to analyze relevant information submitted under the Lobbying Act, make pertinent extracts from it, and adopt an efficient classification and indexing system. But efficient administration would be merely a prerequisite to preparing the data revealed into concise and comprehensible statements which would be made available to press and radio services. If the public is to be informed of the facts disclosed by registration, those facts must get the widest possible circulation in a simplified and intelligible form.

If registration is to become an effective device for revealing group pressures, a special enforcement agency must be established to investigate the accuracy of statements filed and the compliance of those to whom the law applies. It must be staffed to analyze propaganda, assess its effects, accurately summarize detailed financial statements, and make the information thus compiled readily available to press and radio services. Standard administrative procedure which combines civil and criminal sanctions should be adopted to enforce registration. Enforcement of disclosure requirements should depend in the first instance upon publicity; criminal sanctions should be invoked only as a secondary sanction to enforce compliance of recalcitrant registrants with the agency's regulations.

96. 52 STAT. 631 (1938) as amended by 56 STAT. 248 (1942), 22 U. S. C. $\S 611$ (Supp. 1941-1943).

97. See Institute of Living Law, supra note 93 , at 113 ef scq.; id., Administration of Foreign-Agent Registration Act in 87 CoNg. Rec. App. A4417 (1941). The State Department prepared no list of registrants, no efficient indexing system. Registrations vere buried in files and could not be readily inspected by interested parties. The publicity actually prepared by the Department consisted of one press release stating that no stigma was attached to registration.

98. See note 92 supra. 
Such an agency could best operate under the supervision of a permanent joint congressional committee which would be charged with overseeing its methods and determining its policy. Full time personnel should be entrusted with carrying on the investigatory work required. Congressional committees do not, in general, perform repetitive jobs efficiently, and it is unlikely that exposure of pressure group activities would be sufficiently sensational to overcome this handicap. Precedent for a committee in a supervisory capacity can be found in the Reorganization Act itself, which establishes congressional oversight of the Legislative Reference Service, the Congressional Record and the Office of Legislative Council. ${ }^{93}$

New techniques for molding public opinion are constantly evolving and efficient administration of a registration act would require that statutory authority given an enforcement agency be flexible enough to meet all such developments. The act should, therefore, be broad enough to cover all organizations which mold political opinion in any way, and should give the agency authority to exempt those which it found to be outside the pressure group category, e.g., genuinely educational societies. A similar measure of discretion should be given in the determination of the type of information to be submitted. . $^{100}$

Instead of exempting, as does the present Act, all those subject to the narrow provisions of the Corrupt Practices Act, a comprehensive act would include them within its provisions. The problem of regulating election pressures is only part of the larger problem of regulating all political pressures exercised by organized groups. Support of favorable candidates is just one method used by special interests to influence legislation. If such activities were brought within the publicity provisions of an effective lobbying statute present inadequate legislation could be repealed.

\section{Other Provisions Affecting Lobbying}

Any legislative provision designed to improve the knowledge and efficiency of legislators will diminish the likelihood of lobbying abuses. The effectiveness of the professional lobbyist in securing legislation depends in large measure upon his technical knowledge of the complicated subjects of modern laws. Legislators, incapable of personally investigating every governmental problem, have become dependent on these experts for information in the field of their special interest; this information is, of course, often biased. Legislation

99. Sections $203,204,221$. The Library of Congress has always operated under Congressional supervision.

100. A similar conclusion was reached by the House Committee investigating campaign expenditures in 1944 as to administration of the Corrupt Practices Act. Sec H. R. Rer. No. 2093, 78th Cong., 2nd Sess. (1945) 11-2. See also S. 990, 77th Cong., 1st Sess. (1941) (proposing "Office of Minority Relations" to expose sources of poisonous propaganda), analyzed by the Institute of Living Law, 87 Cong. REC. APP. A1038 (1941). 
proposed and drafted by lobbyists has been accepted without proper evaluation of its consequences.

The Reorganization Act has attempted to meet these problems by increasing greatly appropriations to the Legislative Reference Service ${ }^{101}$ and Office of Legislative Counsel. ${ }^{102}$ Employment of research experts to provide both committees and individual members of Congress with unbiased information on all subjects of proposed legislation will weaken the ability of pressure groups to determine congressional policy. Similarly, increased personnel to assist legislators in drafting legislative proposals will make congressmen less eager to accept the services of legal counsel employed by special interests. Presentation of factual data and digests of bills and hearings ${ }^{103}$ to fit the needs of Senators and Representatives should aid them in coming to a rational decision.

The prohibition of private legislation and the transfer of responsibility for determination of governmental tort liability ${ }^{104}$ to the judiciary may also serve to lessen the pressures of those seeking legislative favors. It is not improbable that these provisions aimed only indirectly at lobbying vill be more effective than the direct regulation imposed by the lobbying title of the Act.

\section{ConCLUSION}

It is probable that the Lobbying Act will prove largely ineffective. The loopholes provided by the "principal" requirement, the incompleteness of the information required to be filed, the lack of an adequate enforcement agency, and the weakness of the publicity provisions may combine to make the Act as dead a law as similar state statutes.

101. Section 203. The Legislative Reference Service is established as a separate department of the Library of Congress and appropriations will be increased annually until $19: 19$ when the sum of $\$ 750,000$ will be provided. Specialists in certain fields such as agriculture, education, labor, taxation and others are available for special worls with committees. Some of these specialists have already been appointed and include such recognized experts as Francis Wilcox (State department consultant), Howard Piguet (Chief economist of Tarif Commission), Gustaf Peck (Labor adviser to NRA, WMC, and IVPB), T. A. Goldenweiser (Federal Reserve Board), Ray Manning (Taxation authority), George Galloway, Meyer Jacobstein (Brookings Institute), Dorothy Shafter (educator), T. J. Kreps (Stanford professor), and W. Brooke Graves. For the work of the Service prior to the instant Act, sge Hearings before the Joint Committee on the Organizalion of Congress pursusnt to H. Con. Res. 18, 79th Cong., 1st Sess. (1945) 413 et seq. Similar work in state legislatures is discuesed by Witte, Technical Services for State Legislators (1938) 195 The Awwas 137.

102. Section $20 \pm$ of the Reorganization Act increases appropriation to the Office to $\$ 250,000$ by 1949 for bill drafting services. It is unlikely that this sum will be sufficient to satisfy the requirements of individual legislators, although it should be sufficient to draft bills for committees. Other provisions which will help improve the lnowledge and efficiency of Congress are discussed supre notes $3,4,5,6$.

103. Section 221. A congressional committee is charged with overseeing an improved digest service in the Congressional Record designed to enable congressmen to evaluate more easily legislation coming up for consideration.

104. See note 6 supra. 
Congress has recognized the need for regulating pressure group activities. It has seen the solution not as prohibition of an undesirable practice but as an adaptation of present imperfect mechanisms for expressing group opinion into a political pattern which will utilize this opinion to improve the decisionmaking process. It is to be hoped that this growing realization of the problem will lead Congress to amend the present Act to effectuate more nearly the congressional purpose. 